\title{
THE STRUCTURE OF FLORAL ELEMENTS OF Anchusa officinalis L. CREATING ATTRACTANTS FOR INSECTS
}

\author{
Mirosława Chwil, Elżbieta Weryszko-Chmielewska
}

\author{
Department of Botany, University of Life Sciences in Lublin, ul. Akademicka 15, 20-950 Lublin, Poland \\ e-mail: miroslawa.chwil@.up.lublin.pl
}

Received: 10.02.2009

\section{Abstract}

The present study involved the measurement of size and the micromorphology of the floral elements of Anchusa officinalis $\mathrm{L}$. which are attractants for insects. The structure of the epidermis on the surface of the calyx, petals, throat scales, pistil and nectary were analysed using light and scanning electron microscopy (SEM). For light microscopy observations, semi-permanent slides were prepared, which were treated with Lugol's iodine solution, Sudan III and fluoroglucine.

The dark violet lobes of the corolla of Anchusa officinalis, with a velvety surface, and the throat scales, contrasting with them, belong to the most important optical attractants which lure insects from large distances. The dark pink colouring of the sepals additionally increases the attractiveness of the flowers. The epidermis covering the calyx formed different-sized non-glandular trichomes as well as glandular trichomes. The glandular trichomes were composed of a uni - or bicellular leg and a unicellular head. The colour of the corolla petals was determined by anthocyanins accumulated in the epidermal cells and in the more deeply situated parenchyma. The velvety surface was formed by the conical papillae, densely growing from the adaxial epidermis. The pink-violet throat scales with white hairs, covering the inlet to the tube of the corolla, were found at the inlet to the corolla throat. The longest trichomes on the surface of the scales were located in their lower and middle parts, whereas the shortest ones at their tips. The epidermis of the central part of the throat scales formed small papillae. The trichomes had thin cell walls, large vacuoles, numerous plastids and lipid droplets. The two-parted stigma of the pistil was covered by characteristic expanded outgrowths with wavy edges which performed the functions of structures facilitating the capture of pollen grains.

As a result of the present study it was found that the structures affecting the attractiveness of the flowers, through various light effects within the corolla of Anchusa officinalis, include the papillae on the corolla surface, trichomes of the throat scales and the epidermal cells of the style. The trichomes of the scales can also be responsible for protecting pollen and nectar against rainfall.

Key words: micromorphology, sepals, petals, scales, stamens, stigma, pollen grains

\section{INTRODUCTION}

Anchusa officinalis L. (Boraginaceae) is found in natural stands in western, central and eastern Europe. It occurs in xerothermic communities ( $\mathrm{S} \mathrm{z}$ w e y k ow s c y, 2003). The name of the genus is derived from a Greek work ánchein, which means to choke, to strangle, and it is probably associated with the characteristic structure of the corolla in which the inlet to the tube is covered by strongly haired throat scales (R e je w s k i, 1996). Common bugloss (Anchusa officinalis L.) is a biennial or perennial plant. In the first year, it only forms a rosette of lanceolate basal leaves. In the next years, stiff foliated shoots grow, 60 $-90 \mathrm{~cm}$ in height and covered with bristly hairs. The lower leaves develop petioles, whereas the upper ones are sessile, entire. Cyme inflorescences develop on the branched stems (Podbie lkow s ki and S u d nikWójcikowska, 2003). The plants flower from May to September (R u t k o w s k i , 2006).

Disk, actinomorphic flowers are five-petalled. The corolla is purple-violet or blue, less frequently white or red (S z w e y k ow s c y, 2003). The upper part of the corolla is flatly open and it is $15 \mathrm{~mm}$ in diameter, whereas the lower part forms a straight tube $5-7 \mathrm{~mm}$ in length (W e r y s z k o- C h m i e le w s k a and $\mathrm{Chw}$ il, 2007). In terms of morphological adaptations to entomogamy, bugloss flowers are included in the class of trumpet-shaped flowers. Such flowers are most frequently directed obliquely or vertically upwards; they seldom hang downwards. The stamens and pistils are hidden in the floral tube, at the bottom of which nectar accumulates ( $\mathrm{S} \mathrm{z}$ a fer and $\mathrm{W} \mathrm{oj} \mathrm{t} \mathrm{u} \mathrm{-}$ s i a k o w a , 1969; K u g l e r , 1970). Bugloss flowers are visited by honey bees, bumble bees as well as other Hymenoptera and Diptera. Anchusa officinalis belongs to plants providing large amounts of nectar and pollen to insects (A n d e r s s o n 1988; D r e is i g, 1995; K ołt o w s ki, 2006). In our previous study we dem- 
onstrated that the nectar of this species contains approx. $60 \%$ of sugars (W e r y s z k o- Ch mie le w ska and Chwil, 2007).

Attractants found in insect-pollinated flowers can be divided into signal and food attractants $(\mathrm{K} \mathrm{u}$ g le r, 1970; B a n a szak, 1986). The signal, i.e. so-called secondary, attractants include the following: flower shape, size, odour, colour, glossy elements, signals and colour indicators. The food attractants, which include nectar, pollen and food hairs, are a reward for insects visiting flowers, that is, these are primary attractants.

The aim of this study was to determine the structure of floral elements of Anchusa officinalis which are important in pollination ecology and which contribute to the reproduction success of this species. The micromorphology of sepals, petals, throat scales, elements of the pistil and nectary was investigated. Special attention was paid to the structure of the trichomes covering the surface of the throat scales.

\section{MATERIALS AND METHODS}

The study was carried out in the years 2007 2008. The plants of Anchusa officinalis L. from which inflorescences were sampled came from the Botanical Garden of the Maria Curie-Skłodowska University in Lublin, Poland.

The micromorphology of the following floral elements: sepals, petals, stamens, pistil and nectary, was observed using light and scanning electron microscopy (SEM). The structure of the epidermis on the surface of the sepals, petals, throat scales as well as on the surface of the pistil and nectary was analysed. For light microscopy observations, semi-permanent slides were prepared in glycerol-gelatine, which were stained with Lugol's iodine solution, Sudan III or fluoroglucine. On the cross sections of the perianth, observations of cells were made for the presence of starch and fatty substances as well as for the cell wall structure. Measurements were made of the floral elements and epidermis formations on their surface: nonglandular and glandular trichomes as well as papillae.

The plant samples used for scanning electron microscopy analysis were fixed in glutaraldehyde, next dehydrated in acetone and, after critical point drying in liquid $\mathrm{CO}_{2}$, coated with gold using a Sputter Coater. The floral elements were viewed under a TESLA BS300 microscope.

\section{RESULTS}

The colour of the flower belongs to the most important optical attractants, luring pollinators from large distances. The flowers of Anchusa officinalis have dark violet petals of the corolla with a velvety surface, which are open in a disk shape at the time of flowering
(Figs 1A, B, D). The sepals of the calyx also have dark pink colour, which may contribute to increasing the attractiveness of the flowers (Fig. 1B).

\section{Calyx}

The calyx in the flowers of A. officinalis was ca. $6 \mathrm{~mm}$ long and it was composed of 5 sepals fused in the basal part and sharp-pointed at the tip. Non-glandular and glandular trichomes were found both on the abaxial surface and on the edges of the unfused parts of the sepals (Figs 1 D, 2 A-C). The spiky non-glandular trichomes were live, uni- or bicellular, and they had different sizes (Figs 2 A, B). The smaller trichomes had a swollen basal part, whereas the larger-sized bristly hairs were surrounded at the base by 6 up to 8 cells forming a massive base. The length of the non-glandular trichomes was within a range of $172-778 \mu \mathrm{m}$. The glandular trichomes with a length of approx. $70 \mu \mathrm{m}$ were composed of a uni- or bicellular leg and a unicellular head (Fig. 2C). Numerous anisocytic stomata were found on the abaxial surface of the sepals. Most of the epidermal cells and the guard cells showed irregular striation of the cuticle (Figs $2 \mathrm{C}$-E).

\section{Corolla}

The corolla length reached ca. $10 \mathrm{~mm}$, whereas its diameter 8-9 mm. The length of the corolla tube was 5-7 $\mathrm{mm}$, and the tube diameter approx. $2.5 \mathrm{~mm}$. The colour of the corolla petals was determined by anthocyanins contained both in the epidermal cells and in the more deeply situated parenchyma. The velvety surface of the petals was formed by the conical papillae, densely growing from the adaxial epidermis, which had an average height of $25 \mu \mathrm{m}$ and a basal width of $24 \mu \mathrm{m}$. The surface of the papillae was covered with a thin, slightly striated cuticle (Figs 3B-D). The lower, abaxial epidermis of the petals was smooth (Fig. 3A). The vacuoles of the papillae were stained by pink anthocyanins. There were two layers of parenchyma between the epidermis layers. The thickness of the petal was ca. $75 \mu \mathrm{m}$. Hairy throat scales occurred at the inlet to the corolla tube, forming 5 epipetalous protuberances. The throat scales were pink-violet coloured, whereas the long trichomes of the scales were directed to the central part of the corolla tube, and those closing its inlet were white coloured (Figs 1C, D; 4A, B).

In the flowers of Anchusa officinalis, the throat scales, strongly contrasted with the colour of the corolla, perform, inter alia, the role of well visible colour signals, indicating the location of pollen and nectar in the flower. The throat scales with a length of approx. 1.7 $\mathrm{mm}$ were ligulate in shape (Figs 4C; 5A) and they were structures composed of several layers of cells. The longest trichomes were located in the lower and middle parts of the scales, whereas the shortest ones at their tips (Figs 1C, 4C, D; 5A, B). The epidermis formed small papillae between the trichomes in the central part of the scales (Fig. 5E). The length of the trichomes covering the throat scales was from $100 \mu \mathrm{m}$ up to $600 \mu \mathrm{m}$. These trichomes 

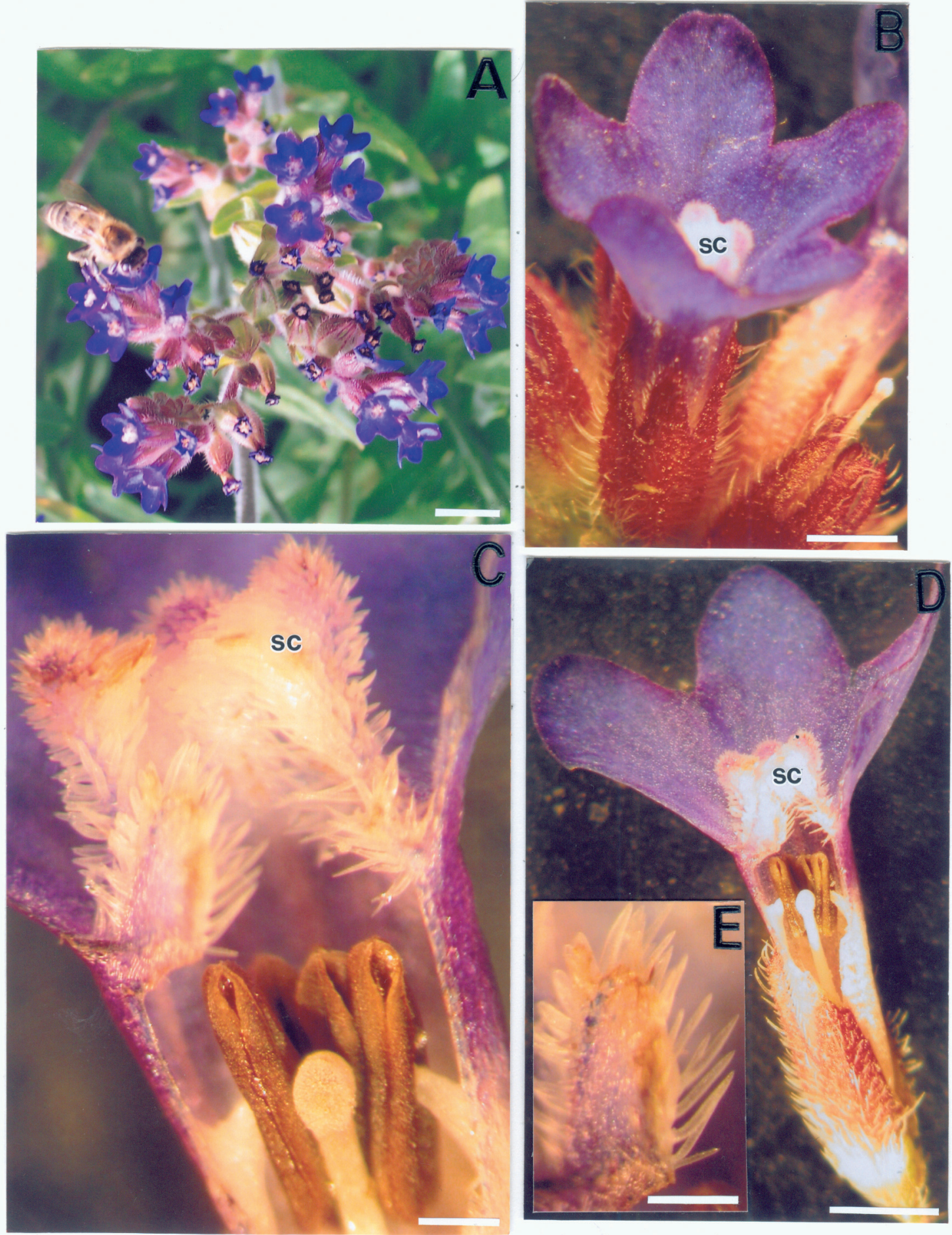

Fig. 1. Flowers of Anchusa officinalis L.

A - Inflorescence at full bloom. Bar $=10 \mathrm{~mm}$.

$\mathrm{B}-\mathrm{B}$ - flower with visible throat scales (sc). Bar $=2 \mathrm{~mm}$.

$\mathrm{C}, \mathrm{D}-$ Longitudinal sections of flowers showing the location of ligulate scales (sc). C $-\mathrm{Bar}=500 \mu \mathrm{m}, \mathrm{D}-\mathrm{Bar}=2 \mathrm{~mm}$. $\mathrm{E}-$ Portion of a haired scale. $\mathrm{Bar}=500 \mu \mathrm{m}$. 

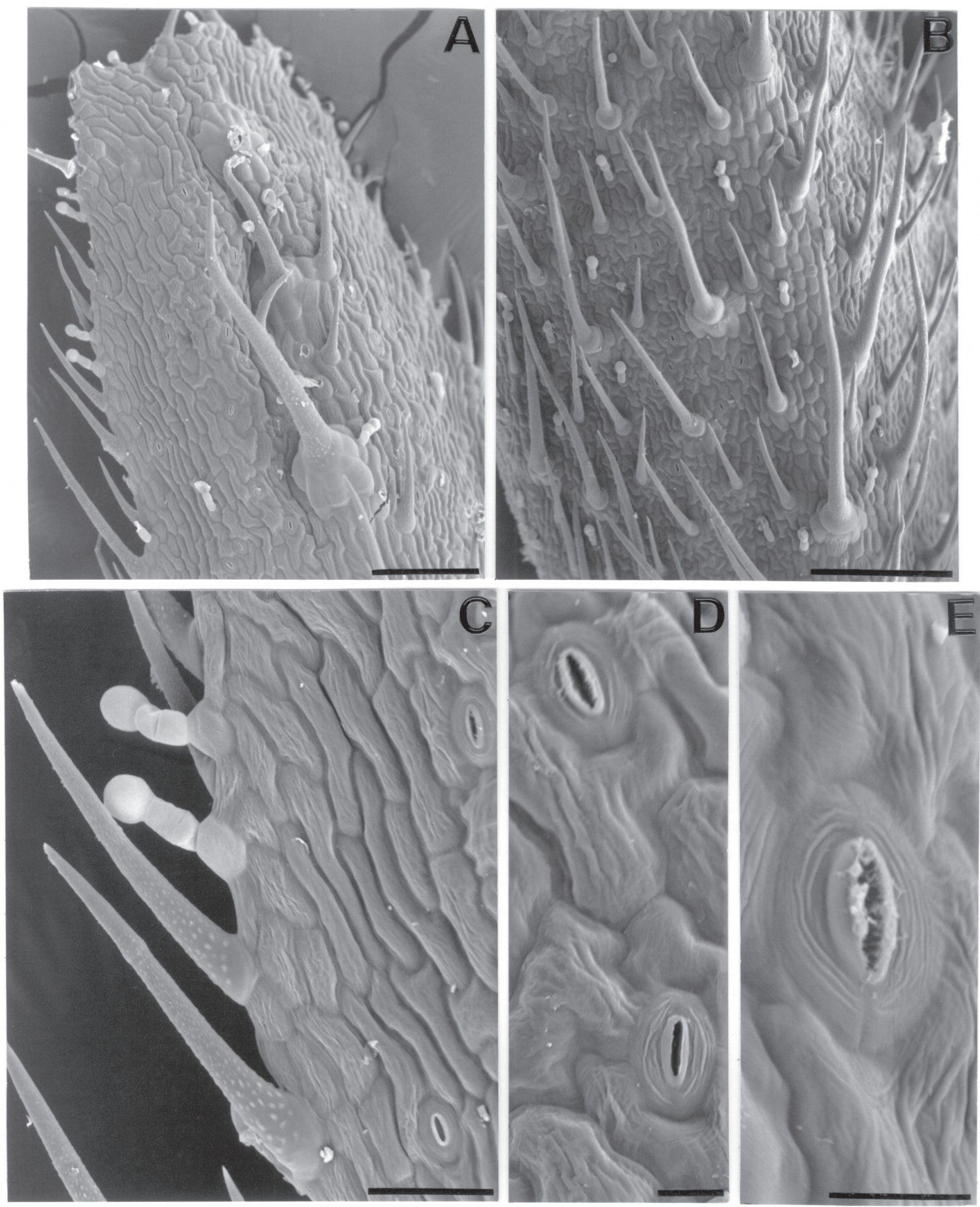

Fig. 2. Portions of sepals of Anchusa officinalis L.

A - Apical part of the abaxial surface of a sepal with different-sized trichomes. Bar $=200 \mu \mathrm{m}$.

B - Non-glandular and glandular trichomes in the abaxial epidermis. Bar $=300 \mu \mathrm{m}$.

C - Edge part of a sepal with non-glandular and glandular trichomes. Bar $=70 \mu \mathrm{m}$.

D, E - Stomata in the abaxial epidermis. D, E - Bar $=20 \mu \mathrm{m}$. 

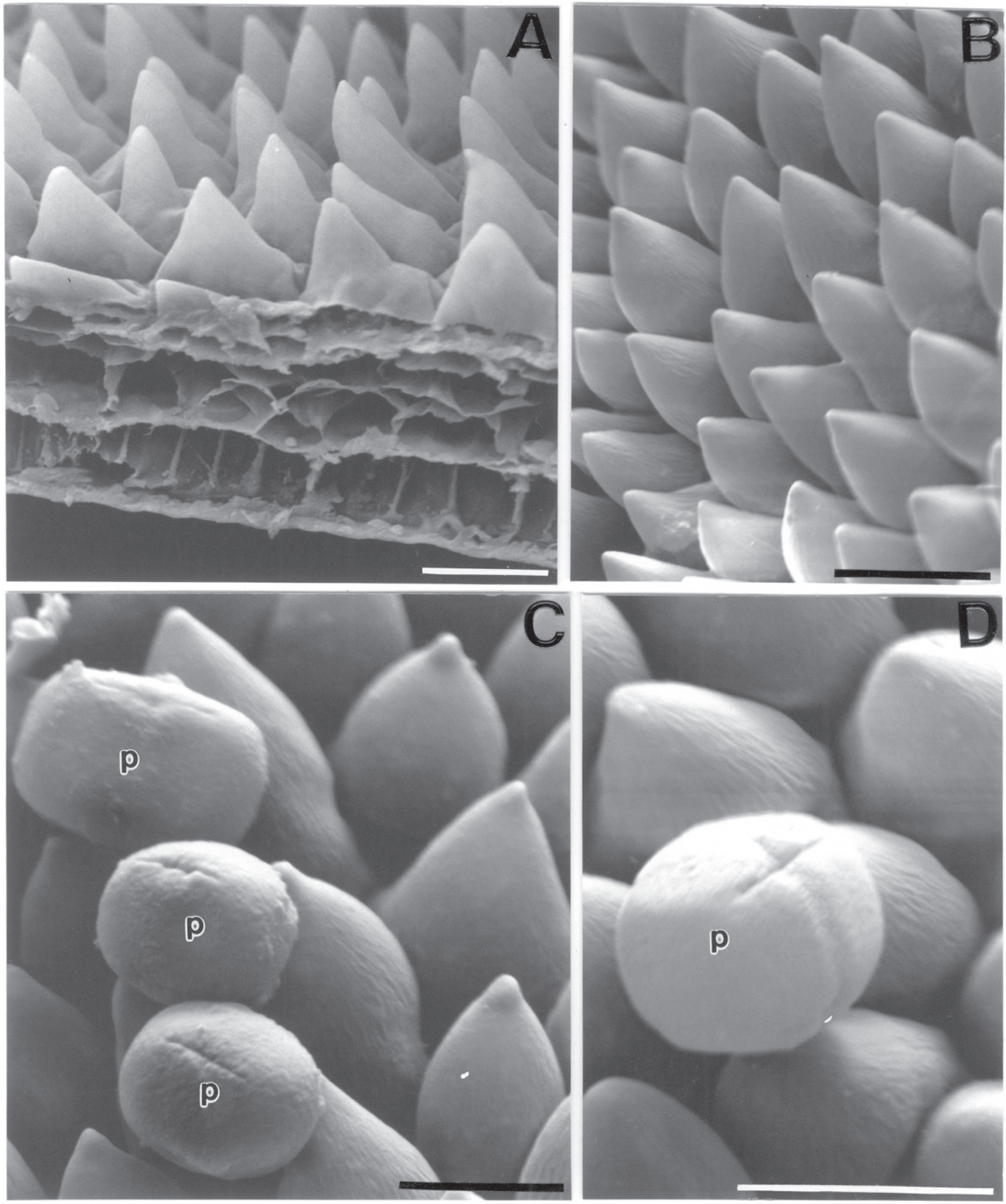

Fig. 3. Portions of the adaxial surface of petals of Anchusa officinalis L.

A - Cross section of a petal with visible papillae.

B - Papillae densely covering the surface.

C, D - Pollen grains (p) in the depressions between papillae. A - D - Bar $=20 \mu \mathrm{m}$. 

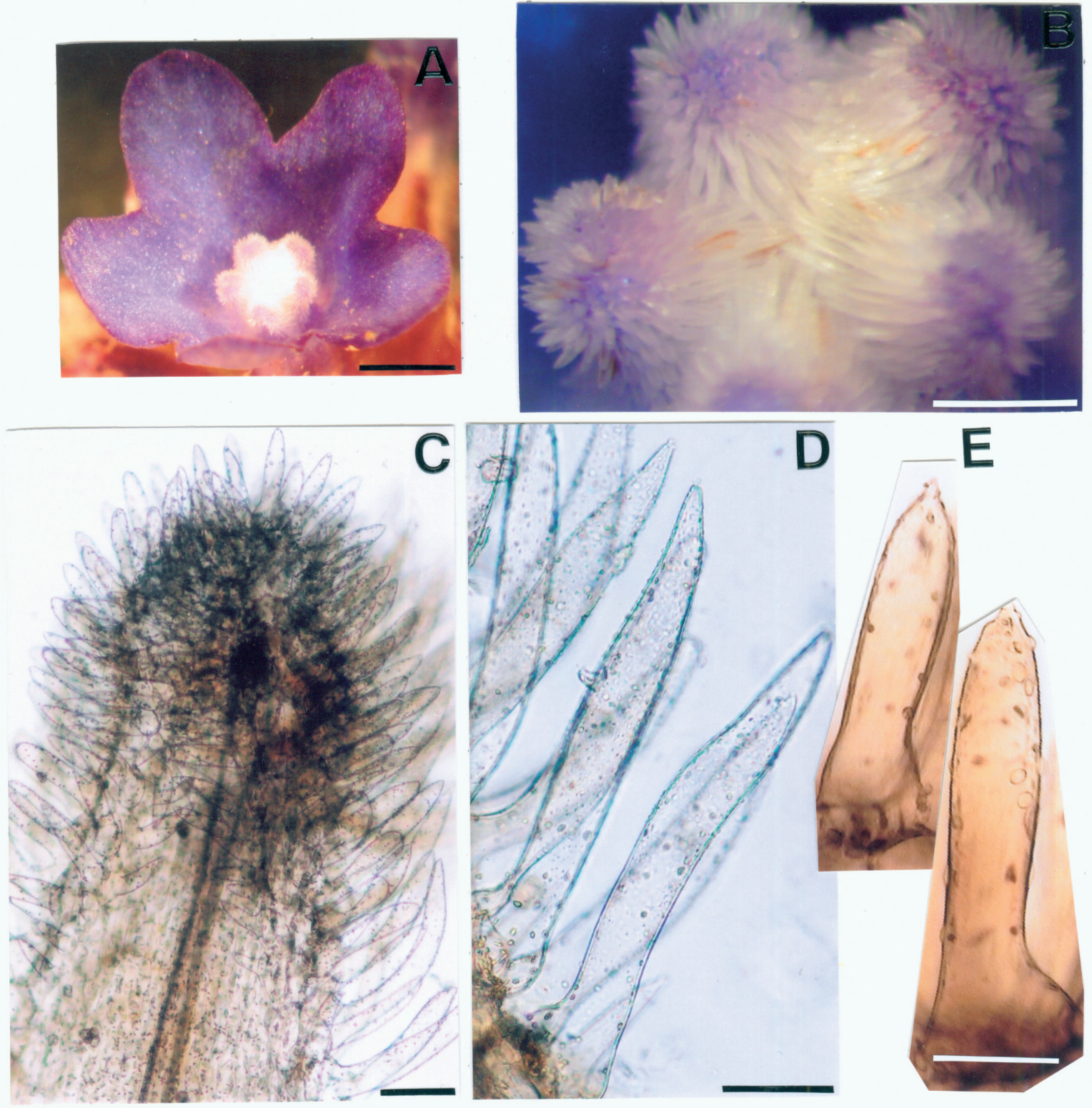

Fig. 4. Throat scales restricting the inlet into the tube of the corolla of Anchusa officinalis L. A - The colour of bright scales forms a strong contrast with corolla lobes. Bar $=2 \mathrm{~mm}$. $\mathrm{B}-$ The surface of the scales is covered by different-sized trichomes. B $-\mathrm{Bar}=500 \mu \mathrm{m}$.

C, D - The longest trichomes are visible in the lower part of a ligulate scale. C, D - Bar $=200 \mu \mathrm{m}$. $\mathrm{E}-$ Living trichomes of the scales contain numerous plastids. Bar $=100 \mu \mathrm{m}$. 

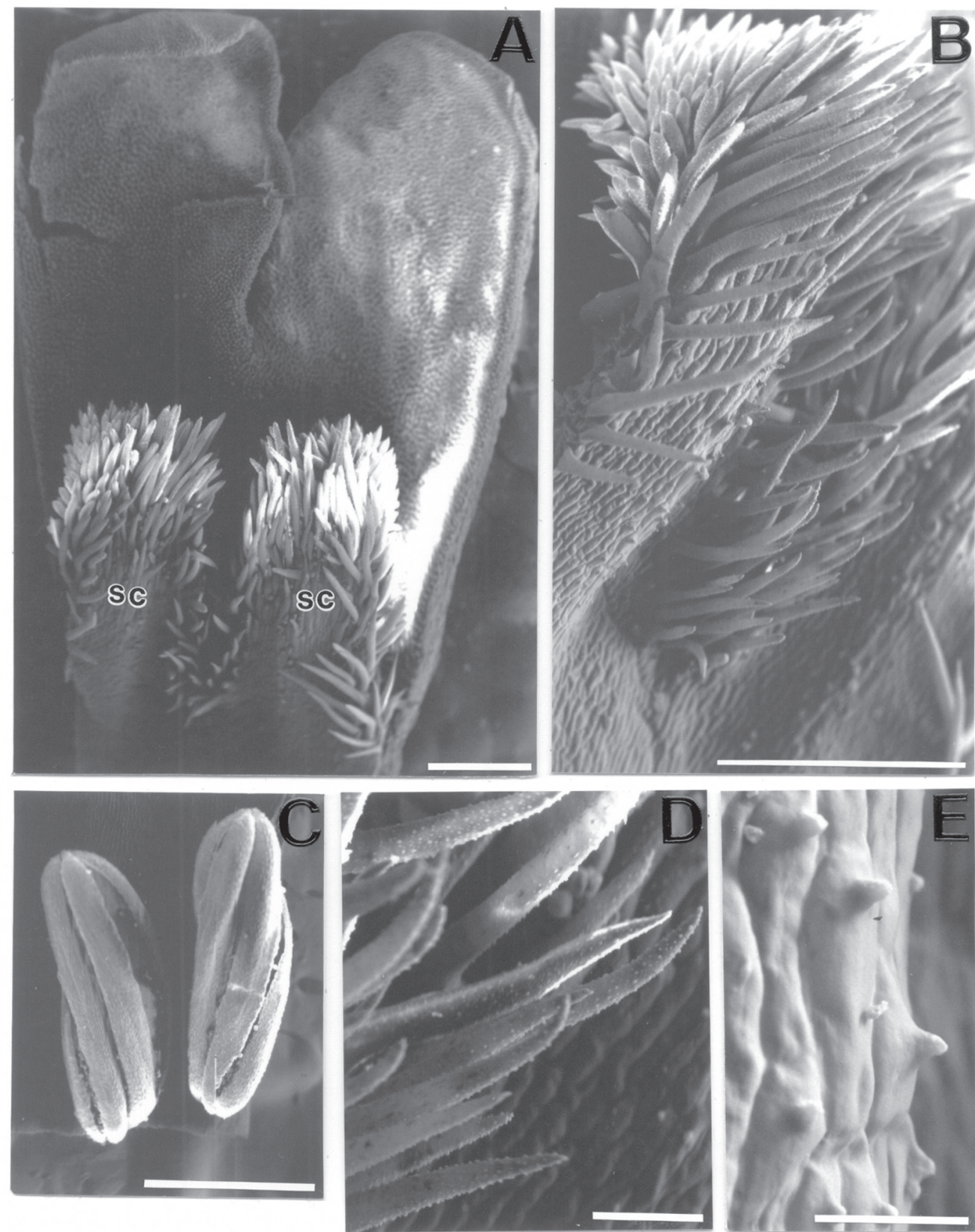

Fig. 5. Portions of a corolla of Anchusa officinalis L. with throat scales and stamens.

A - Two neighbouring lobes with scales. Bar $=800 \mu \mathrm{m}$.

B, D - Trichomes of different length on the surface of the scales (sc). B - Bar $=20 \mu \mathrm{m}$,

$\mathrm{D}-\mathrm{Bar}=100 \mu \mathrm{m}$.

C - Stamens with short filaments fused to the corolla below the scales. Bar $=1 \mathrm{~mm}$.

$\mathrm{E}-$ Outgrowths of cells of the epidermis occurring in the middle part of the scales. Bar $=50 \mu \mathrm{m}$. 

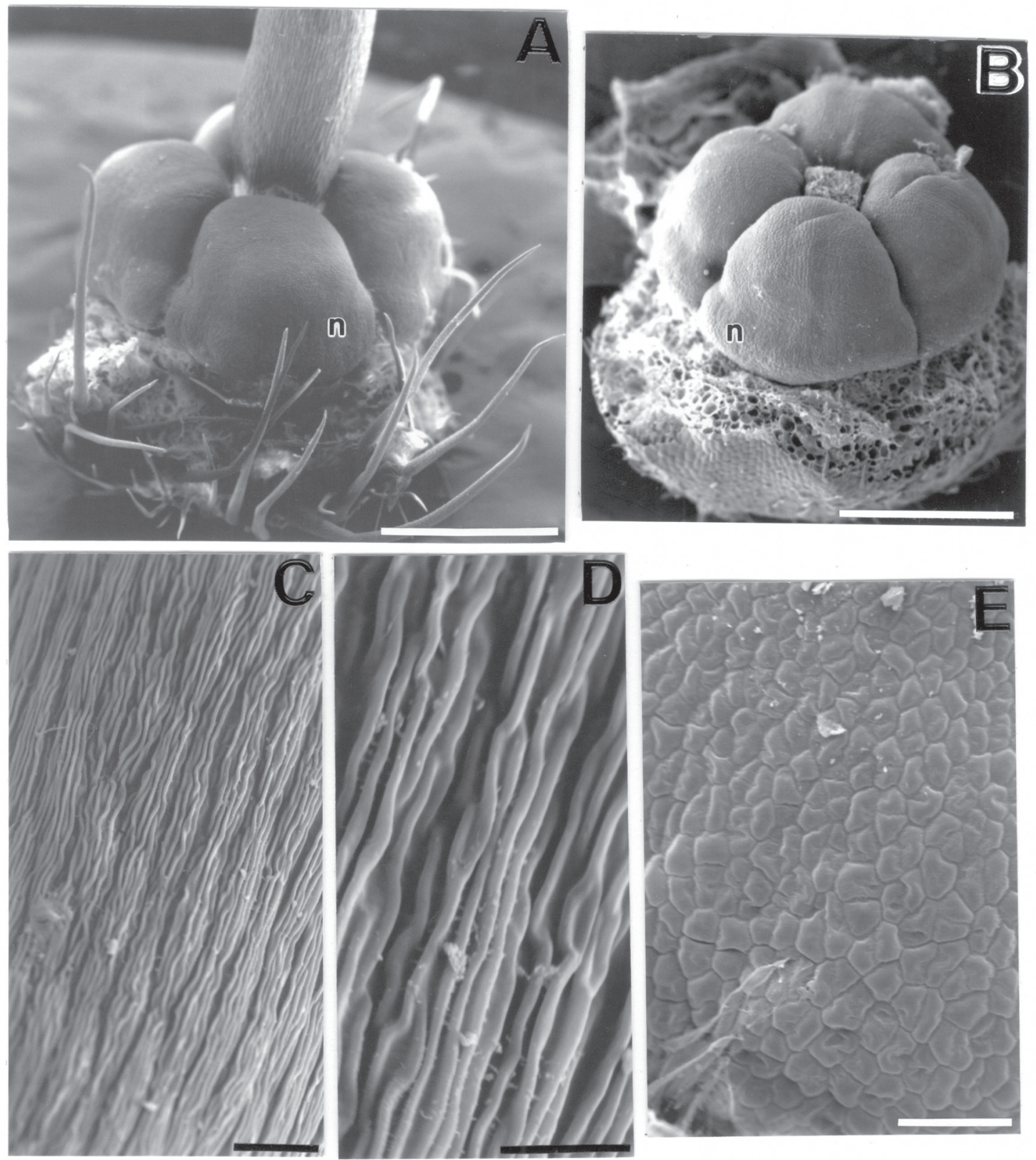

Fig. 6. Portions of a pistil and nectary of Anchusa officinalis L.

A, B - Four-parted ovary with a nectary (n) at the base. A, B - Bar $=500 \mu \mathrm{m}$.

C, D - Portion of the style with elongated epidermal cells and massive cuticular striae. $C-B a r=100 \mu \mathrm{m}, \mathrm{D}-\mathrm{Bar}=20 \mu \mathrm{m}$. $\mathrm{E}-$ Portion of the nectary surface. Bar $=50 \mu \mathrm{m}$. 

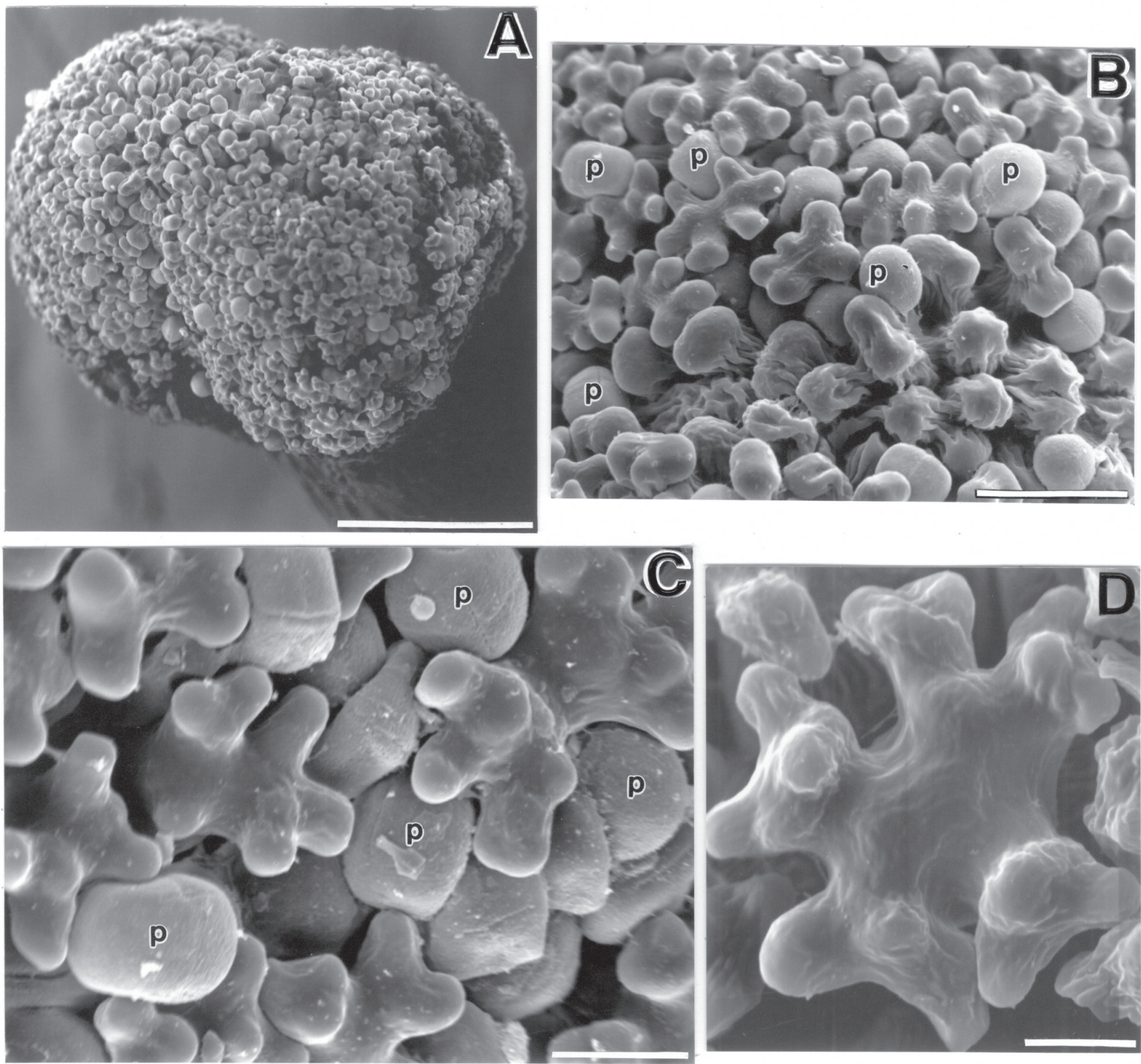

Fig. 7. Stigma of a pistil of Anchusa officinalis L. with characteristic outgrowths.

A - Papillae densely cover a protruding stigma. Bar $=200 \mu \mathrm{m}$.

$\mathrm{B}, \mathrm{C}-$ Pollen grains are retained between the stigma outgrowths with wavy edges (p). B $-\mathrm{Bar}=50 \mu \mathrm{m}, \mathrm{C}-\mathrm{Bar}=20 \mu \mathrm{m}$. D - Upper surface of the stigma outgrowth with branched edges. Bar $=10 \mu \mathrm{m}$. 
were live, unicellular. They had thin cell walls, at places covered with tiny outgrowths (Fig. 5D). Large vacuoles were found in the cells of these trichomes as well as numerous, tiny plastids in the cytoplasm (Figs 4D, E). The presence of small lipid droplets was found inside them. Violet anthocyanins were found in the vacuoles of the parenchyma.

\section{Androecium}

The stamens (5), alternating with the lobes of the corolla, consisted of short filaments and elongated heads. They grew from the upper part of the corolla tube. The apical part of the stamen heads was adjacent to the lower region of the throat scales (Fig. 1C). The stamen filaments were approx $0.6 \mathrm{~mm}$ in length and the heads $1.8 \mathrm{~mm}$. The anthers dehisced longitudinally inside the corolla tube and they were slightly twisted after pollen release (Fig. 5C).

\section{Pistil}

The pistil, similarly to the stamens, was closed in the corolla tube (Figs 1C, D). The height of the ovary was approx. $0.55 \mathrm{~mm}$ and the length of the pistil's style approx. $5 \mathrm{~mm}$. The four-parted ovary was rounded and smooth at the apex (Figs 6A, B). The nectary was located at its basal part (Fig. 6B). The epidermis of the nectary is characterised by the presence of fine, multiwalled cells (Fig. 6 E). No stomata were found on the surface of the nectary gland.

The epidermis of the style consisted of elongated cells whose outer walls were covered with massive cuticular striae running parallel to the long axis of the cells (Figs 6C, D).

The two-parted convex stigma of the pistil was covered by characteristic expanded outgrowths with wavy edges (Figs 7A-D). The diameter and height of the stigma were, respectively, $480 \mu \mathrm{m}$ and $400 \mu \mathrm{m}$. Pollen grains were visible between the outgrowths, whose edges moved (Figs 7B, C). The wavy outgrowths of the stigma performed the functions of structures facilitating the capture of pollen grains which placed themselves in the hollows formed between the position changing edges of these outgrowths.

\section{DISCUSSION}

The violet-blue colouring of the corolla petals of Anchusa offcinalis corresponds to the frequently found colour of entomophilous flowers in the moderate climate zone of Europe ( $\mathrm{S} \mathrm{z}$ a fer and $\mathrm{W}$ oj t u s i a k ow a, 1969). As a result of our study we found that the colour of the petals in Anchusa officinalis comes from anthocyanins contained in the vacuoles of both the epidermal cells and parenchyma. K u g l e r (1970) reports that the colouring of the corolla petals in $A$. officinalis is determined by complementary pigments located in particular tissues. The cell sap in the epi- dermal cells is red coloured, whereas the contents of the vacuoles in the mesophyll located beneath the epidermis has blue colour, which gives different shades to flowers.

The white-pink strongly haired throat scales, covering the inlet to the tube of the corolla, are an important visual attractant in the flowers of Anchusa. Due to a large contrast with the colour of the petals, they make flowers well visible from far away. The densely packed trichomes of the throat scales probably protect the nectar and pollen against rainfall and they can restrict access to the inside of the flowers for undesired insects which do not pollinate flowers. Another function of bright hairs belonging to the scales can be the scattering of sunlight, so that it reaches the inside of the corolla tube to a smaller degree, which may be the protection of the anthers and the stigma of the pistil against ultraviolet radiation. $\mathrm{S} \mathrm{z}$ a fe $\mathrm{r}$ and $\mathrm{W} \mathrm{ojtu-}$ $\mathrm{s}$ i a k ow a (1969) report that trichomes found in the epidermis of the corolla petals, for example, capitate or villous trichomes, may impact the effects of illumination of the inside of flowers by sunlight. Due to the content of fat droplets in the cytoplasm of the trichomes of the throat scales, one may presume that the scales are a place of production of odorous substances in the flowers of Anchusa officinalis.

The type of surface of the petals, which can be glossy, matt or velvety, contributes to increasing the attractiveness of flowers. In the case of Anchusa officinalis, in the adaxial epidermis we found the presence of conical papillae which are responsible for the effect of velvety lustre of the petals. According to $\mathrm{Ku} g \mathrm{le} \mathrm{r}$ (1970), the effect of velvety surface is created in flowers thanks to the presence of small papillae, at a particular sunlight incidence angle. These papillae reflect and refract sunlight in a definite way. The warm and saturated colours of the petals deepen the effect of velvet. The colourful calyxes may also complement insect attraction in the inflorescences.

Different properties of the epidermis in particular parts of the Anchusa flowers may provide various light effects to insects. In accordance with the data of K u g l e r (1970), the velvety lustre in flowers is created by parallelly arranged fibrous structures found in them. The elongated epidermal cells of the style of the pistil, covered by a layer of cuticle with clear striae running in parallel to the long axis of the organ, can be included in such structures.

Due to its location in the flower, according to Bernardello (2007), the nectary in Boraginaceae can be generally included in gynoecial nectaries, whereas within this type it represents the variant of ovarian nectaries. This author reports that the nectary in representatives of this family forms a ring at the base of the superior ovary. Our study shows that in Anchusa 
this ring is divided into four distinct parts, corresponding to the compartments of the ovary. This nectary differs in size and shape from the nectaries in the flowers of other representatives of this family: Myosotis (Weryszko-Chmielewska 2003) and Symphytum (S t p i c z y ńs k a, 2003). Moreover, we did not find stomata in the nectary of Anchusa, whereas in other species of this family nectar is secreted through nectarostomata.

The study of A nders s on (1988) shows that the flowers of $A$. officinalis are self-incompatible and they require cross pollination by insects. A. officinalis is a valuable food plant for insects ( $\mathrm{K} \mathrm{o} \mathrm{t} \mathrm{o} \mathrm{w} \mathrm{s} \mathrm{k} \mathrm{i,}$ 2006; P o g or ze le c, 2006). K o ł t o w s k i, (2006) reports that the flower of $A$. officinalis lives two days. It produces 1-2 mg of sugars in its nectar. Honey yield per one hectare of crops is $170 \mathrm{~kg}$. The weight of pollen which can be provided by plants of this species grown on the abovementioned area is estimated at $30 \mathrm{~kg}$.

\section{REFERENCES}

Anders s on S. 1988. Size-dependent pollination efficiency in Anchusa officinalis (Boraginaceae): causes and consequences. Oecologia, 76 (1): 125-130.

B a n a z a k J. 1986. Pszczoły i zapylanie roślin. Państwowe Wydawnictwo Rolnicze i Leśne, Poznań.

B ernarde11 o G. 2007. A Systematic Survery of Floral Nectaries. [In:] Nectaries and Nectar. W. Nicolson, M. Nepi, Pecini (eds.). Springer, Dordrecht.

Dreisig H. 1995. Ideal free distributions of nectar foraging bumblebees. Oikos, 72 (2): 161-172.

Kołtowski Z. 2006. Wielki atlas roślin miododajnych. Przedsiębiorstwo Wydawnicze Rzeczpospolita S.A., Warszawa.

Kugler H. 1970. Blütenökologie. Gustaw Fischer Verlag, Stuttgart.

Podbielkowski Z., Sudnik-Wójcikowska B. 2003. Słownik roślin użytkowych. Państwowe Wydawnictwo Rolnicze i Leśne, Warszawa.

Pogorzelec M. 2006. Rośliny miododajne. Wydawnictwo Sądecki Bartnik, Nowy Sącz.

Rejew ski M. 1996. Pochodzenie łacińskich nazw roślin polskich. Książka i Wiedza, Warszawa.

Rutkowski L. 2006. Klucz do oznaczania roślin naczyniowych Polski niżowej. Wydawnictwo Naukowe PWN, Warszawa.

St piczy ń ska M. 2003. Sekrecja nektaru w kwiatach żywokostu lekarskiego (Symphytum officinale L.) i jego skład chemiczny. / The secretion of nectar in Symphytum officinale L. and its chemical composition. Acta Agrobot. 56 (1-2): 27-31.

Szafer W., Wojtusiakowa H. 1969 Kwiaty i zwierzęta. Zarys ekologii kwiatów. Państwowe Wydawnictwo Naukowe, Warszawa.
Szweykows cy A, J. 2003. Słownik botaniczny. Wyd. Wiedza Powszechna, Warszawa.

Weryszko-Chmielewska E. 2003. Morphology and anatomy of floral nectary and corolla outgrowths of Myosotis sylvatica Hoffm. (Boraginaceae). Acta Biol. Crac. Ser. Bot. 45 (1): 43-48.

Weryszko-Chmielewska E., Chwil M. 2007. Characteristics of floral nectary and nectar of common bugloss (Anchusa officinalis L.). Journ. Apic. Sci. 51 (2): 25-29.

\section{Struktura elementów kwiatowych Anchusa officinalis L. tworzących atraktanty dla owadów}

\section{Streszczenie}

Przeprowadzone badania obejmowały pomiary wielkości oraz mikromorfologię elementów kwiatowych Anchusa officinalis L. stanowiących atraktanty dla owadów. W mikroskopie świetlnym i skaningowym elektronowym (SEM) analizowano strukturę epidermy na powierzchni kielicha, płatków korony, osklepek, słupka i nektarnika. Do obserwacji w mikroskopie świetlnym przygotowano półtrwałe preparaty, które traktowano: płynem Lugola, Sudanem III i fluoroglucyną.

Ciemnofioletowe latki korony Anchusa officinalis o aksamitnej powierzchni i kontrastujące z nimi jasne osklepki należą do najważniejszych atraktantów optycznych przywabiających owady z dużych odległości. Ciemnoróżowe zabarwienie działek kielicha zwiększa dodatkowo atrakcyjność kwiatów. Epiderma okrywająca kielich tworzyła włoski mechaniczne różnej wielkości oraz włoski gruczołowe. Włoski gruczołowe składały się z jedno- lub dwukomórkowej nóżki i jednokomórkowej główki. Barwę płatków korony warunkowały antocyjany zgromadzone w wakuolach komórek epidermy i głębiej leżącej parenchymy. Aksamitną powierzchnię tworzyły zwarcie wyrastające z doosiowej epidermy stożkowate papille. Przy wlocie do gardzieli korony występowały różowo-fioletowe osklepki z białymi włoskami osłaniającymi wlot do rurki korony. Najdłuższe włoski na powierzchni osklepek występowały w dolnej i środkowej ich części, a najkrótsze na szczycie. Epiderma centralnej części osklepek wytwarzała niewielkie papille. Włoski miały cienkie ściany komórkowe, duże wakuole, liczne plastydy i lipidowe krople. Dwudzielne znamię słupka było pokryte charakterystycznymi rozszerzonymi wyrostkami o pofałdowanych brzegach, które pełniły funkcje struktur ułatwiających zatrzymywanie ziaren pyłku.

W wyniku badań stwierdzono, że do struktur wpływających na atrakcyjność kwiatów poprzez zróżnicowane efekty świetlne w obrębie korony Anchusa officinalis należą papille na powierzchni płatków, włoski osklepek oraz komórki epidermy szyjki słupka. Włoski osklepek mogą być również odpowiedzialne za osłonę pyłku i nektaru przed deszczem. 